\title{
Når kvinder kommer til orde
}

\section{KONSTRUKTIONER AF MUSLIMSKE KVINDER PÅ ARABISK \\ RELIGIØST TV}

Arabisk religiøst tv har lanceret en lang række programmer henvendt til kvinder, der handler om alt fra samfundsproblematikker, religiøs fortolkning til livsstilsspørgsmål. Programmerne giver ikke kun nye bud på muslimske kvindeidentiteter, men bryder med tabuiserede temaer som $\mathrm{fx}$ vold mod kvinder, prostitution og den kvindelige biologi.

Af Ehab Galal, ph.d.-stipendiat på Tværkulturelle og regionale studier, Københavns universitet.

Siden begyndelsen af 9o'erne er arabiske satellitkanaler vokset eksplosivt i antal og i variationen af programmer. Udviklingen har blandt andet igangsat en debat om satellit-tv's betydning for demokratiseringsprocessen i Mellemøsten, ligesom man diskuterer udviklingen af en global muslimsk offentlighed. I I begge tilfælde diskuteres transnationalt tv's potentiale for at udfordre statslig censur og dermed åbne for fri meningsudveksling og ikke-kontrollerede informationer. I et noget mindre omfang er spørgsmålet om de transnationale mediers potentiale som redskab for forandring af kvindens rolle og status i de arabiske lande blevet rejst. For selv om udviklingen har skabt mere pluralistiske og friere arabiske medier, er spørgsmålet, om de samtidig har åbnet for andre fremstillinger af kvinder og har givet plads til kvinder i medierne? ${ }^{2}$

Ét af de steder, hvor kvinder er temaet, er $\mathrm{i}$ en række religiøse kvindeprogrammer, der sendes på de nye religiøse satellitkanaler. Heri diskuteres og analyseres kvindens roller på grundlag af islam, hvor religionen bruges som det ideologiske afsæt for forandring. Dette afspejler en situation, hvor den måske mest indflydelsesrige kvindebevægelse i de arabiske lande de sidste tyve år har været den såkaldte islamiske feminisme. ${ }^{3}$ I begge sammenhænge bliver kravet om kvinders ligestilling rejst med henvisningen til islam.

Det er med dette udgangspunkt, at jeg i det følgende vil analysere en række religiøse programmer på satellit-kanalen Iqraa ${ }^{4}$ med særligt fokus på udfordringen af de eksisterende kønsroller inden for rammen af islam og diskutere, hvordan dette er muligt. Spørgsmålet er, i hvor høj grad sådanne religiøse programmer udfordrer eller fastholder traditionelle diskurser og i hvilken grad programmerne giver plads til kvindernes egne selvfremstillinger. Efter en kort introduktion til udviklingen af arabisk satellit-tv og religiøse kvindeprogrammer vil jeg analysere tre eksempler på programtyper, som på hver deres måde bidrager til diskussionen af muslimske kvinders rolle i de arabiske samfund.

\section{Tv og kønsrepræsentationer}

I Mellemøsten betyder statscensuren på nationalt tv, at hverken journalister, produI3 8 
center, instruktører eller andre mediefolk af begge køn - frit har kunnet formidle alternative billeder af kønsroller og -identiteter, uanset hvad de har haft af intentioner. Det egyptiske nationale tv-selskab ERTU (Egyptisk Radio og Tv-Union) er et godt eksempel. Her har det været forbudt for ethvert program, der berører kvinders status, at kritisere religionen og traditionerne, at true familiebåndene eller nedvurdere ukrænkeligheden af familieværdier. ${ }^{5}$ Disse hensyn til religionen og traditionen har medvirket til et temmelig stereotypt kvindebillede i nationale medier. Nahed Ramzy har analyseret egyptiske tv-serier og kommer frem til, at kvinder generelt fremstilles som passive, mens mænd er aktive; kvinder er følelsesstyrede, mens mænd er rationelle, og den væsentligste rolle for kvinden er ifølge serierne rollen som mor, hustru eller søster. ${ }^{6}$ Samtidig bliver kvindens samfundsmæssige rolle indskrænket til biologisk at reproducere nationen gennem at føde børn, samt beskytte og formidle nationens kulturelle og religiøse traditioner.7 Ifølge Ramzy afspejler de arabiske medier hverken den virkelighed, hvor kvinder i de arabiske samfund reelt har opnået professionelle og indflydelsesrige stillinger, eller de kulturelle og sociale forskelle, der eksisterer mellem arabiske kvinder inden for de enkelte arabiske lande og mellem landene. ${ }^{8}$

Med i dag mere end 350 arabisk-sprogede satellit-kanaler står de nationale medier over for en konkurrent, der potentielt har et andet grundlag for at udfordre disse kønskonstruktioner. Udfordringen er dog relativ, da en stor del af disse transnationale kanaler i realiteten blot er nationalt tv eller private kanaler med tætte bånd til statsmagten og dermed stadig underlagt nation- alstatslige begrænsninger. Men derudover kommer en lang række af nationale private og ofte kommercielle kanaler, mere internationalt orienterede arabiske kanaler som al-Jazeera og al-Arabiya, og en lang række såkaldte religiøse kanaler. Udviklingen har blandt andet betydet, at man på al-Jazeera har kunnet se programmer, der har taget fat på kontroversielle spørgsmål som vold mod kvinder, kvinder i fængslerne, kvindelige tjenestefolk, kvinder i væbnede konflikter, og prostitution. ${ }^{9}$

Samtidig har de nationale kanaler mistet monopolet på fremstillingen af den rette islam, som har været tæt forbundet med konstruktionen af nationen. I stedet repræsenterer medierne nu en diversitet af forskellige muslimske stemmer og værdier, der går på tværs af nationale grænser. Heriblandt er en række religiøse satellit-tvkanaler som al-Majd, al-Risala, og Iqraa. De fleste af disse kanaler har som mål at lave programmer i overensstemmelse med lokale og religiøse værdier, samtidig med at de ser sig selv som en modvægt til ødelæggende udenlandsk indflydelse.

\section{Iqraa}

Iqraa er den første islamiske satellit-tv. Den blev lanceretden 2I. oktober I998 af ART (Arabisk Radio og TV), hvis ejer er den saudiarabiske forretningsmand og milliardær Salih Kamel. ART består af en række ikke religiøse temakanaler, hvor Iqraa skiller sig ud ved at være religiøs og primært at sende egne programmer. Programmernes fokus er islamiske værdier, som ikke er nærmere defineret. Målene er I) at støtte den arabisk-islamiske nations værdier og fremhæve den moderate islamiske identitet, 2) at fastslå Koranen og Sunna $^{\text {Io }}$ som islams fundamenter, 3) at 
beskytte den arabisk-islamiske nation mod importeret ikke-islamisk kultur, 4) at støtte relationerne mellem de forskellige arabiske lande, og 5) at producere kvalitetsunderholdning for den arabiske familie. ${ }^{\text {II }}$

Iqraa sender en række forskellige programmer, der henvender sig til et kvindeligt publikum. Der er programmer, der direkte lanceres som kvindeprogrammer og som allerede i programtitlen henvender sig til kvinder, fx "Troende kvinder" (Nisaa mominaat), "Kvindernes fatwa" (Fatwa anNisaa), "Islamisk retsvidenskab for kvinder" (Fiqh in-Nisaa). En anden type af programmer lanceres ikke som specifikke

\section{Har mere pluralistiske og friere arabiske medier samtidigt åpnet for \\ andre fremstillinger av kvinder?}

kvindeprogrammer, men henvender sig alligevel til kvinder ved at rejse spørgsmål om kvinders liv fra forskellige vinkler. Derudover er studieværten i disse programmer en kvinde. Programmerne følger de samme genrer, som ellers er populære på arabisk tv. Talkshowet, fatwa-programmer og livsstilsprogrammer. Der er selvfølgelig en række variationer under hver genre, men de tre genre opfylder hvert deres formål. Talkshowet rejser en række samfundsrelevante spørgsmål, hvor samtalen og diskussionen er et mål i sig selv. Fatwa-programmerne er i højere grad et redskab til at formidle det rette svar, hvor målet er at udlægge islams sandhed. Livsstilsprogrammerne dækker forskellige måder at vælge at leve livet på og fokuserer på de individuelle valg og materielle vilkår, mens målet er at præsentere og demonstrere attraktive muligheder. Fælles for programmerne er, at kvinderne selv kommer til orde som studieværter, gæster og seere, uden at det i øvrigt udelukker mandlig deltagelse.

\section{Hjemløse kvinder i "Før dommedag"}

Talkshowene er typisk karakteriserede ved en vis grad af interaktivitet og giver dermed ordet til kvinderne selv gennem programmer, hvor seerne kan ringe ind, eller ved at interviewe kvinderne i deres eget miljø. For det meste er der samtidig eksperter i studiet, der kommenterer eller analyserer en specifik problemstilling.

Talkshowet "Før dommedag” (Qabil an tuhaasabu) er et ugentligt program på Iqraa, der sendes i den bedste sendetid. Programmets værtinde er Basma Wahba, der har rollen som en direkte og til tider pågående interviewer, der stiller kontroversielle spørgsmål. Hun er klædt i overensstemmelse med den seneste islamiske mode, det vil sige med tørklæde (hijab) og figursyet dragt i afstemte farver. Som titlen antyder, spiller den islamiske tradition eller sharia en central rolle og forholdes i hvert program til programmets aktuelle case. Programmet behandler de samme kontroversielle spørgsmål, som sekulære talkshows på al-Jazeera er blevet kendt for på grund af kanalens progressive holdning til en række tabuiserede temaer, fx spørgsmålet om kvindelige fængselsindsatte. Andre eksempler er hjemløse piger og unge kvinder, der lever på gaden og har et liv med seksuelle og voldelige overgreb, adskillige seksuelle relationer, prostitution, stofmisbrug, risikoen for at få børn uden for ægteskab og tilbagevendende arrestationer. 
Kvinder, der lever på gaden, var emnet for to efterfølgende programmer i "Før dommedag”, der blev sendt i september 2006. ${ }^{\mathrm{I3}}$ Programmerne fortæller historien om fire piger, der alle lever på gaden i Cairo. De fortæller hver især deres egen historie. Interviewene med pigerne er det dominerende indslag igennem begge programmer, mens rammen for interviewene er typisk for talkshowet som genre. Scenen for talkshowet er en parklignende have, hvor tv-værten sidder sammen med forskellige eksperter med hver sin specialiserede viden om programtemaet. De bliver bedt om at kommentere den specifikke sag eller diskutere mere principielle aspekter af temaet. Det andet program, som jeg her vil give eksempler fra, indledes med korte skiftende klip fra henholdsvis interviewet med pigen Aya, eksperternes udtalelser og tv-værten, der stiller spørgsmål. Tv-værtens retoriske spørgsmål er for eksempel: "Er disse piger ofre, eller er de selv skyld i deres problemer? Fortæller de sandheden, eller lyver de? Hvilke omstændigheder har tvunget pigerne til at leve, som de gør?” Klippene fra interviewet med Aya viser blandt andet billedet af både Aya og tv-værten med tårer i øjnene under Ayas historie. Grædende spørger Aya Gud om tilgivelse for det liv, hun har levet, fulgt at tv-værtens "hvis Gud vil", hvorefter tv-værten fortsætter: "Kommer dette fra dit hjerte?" Aya bekræfter dette med eftertryk.

Rammen er dermed en angrende ung kvinde, som ikke kun fremstiller livet på gaden som grusomt og fuldstændigt destruktivt, men også præsenterer dette liv som forkert og umoralsk. På trods af den religiøse ramme og tilstedeværelsen af en muslimsk sheikh som en ekspert, hvis rolle er at forholde sig til Ayas liv på baggrund af en islamisk fortolkning, er programmet overraskende loyalt over for Aya og dét, hun ser, som afgørende for sin situation. Der er tale om en lang historie om forsømmelse fra både moderens og systemets især politiets og socialarbejdernes - side, og ikke mindst de mange mænds udnyttelse af den ubeskyttede position, som den forladte Aya har befundet sig i. Hun får i programmet i høj grad lov til at udtrykke sig selv på egne betingelser. Tv-værten afbryder ikke Ayas historie med kritiske spørgsmål under interviewet, men spørger gentagne gange pigen om at forklare og gå mere i detaljer eller give udtryk for sine følelser i en specifik situation. Ved på denne måde at give stemme til Aya, både konkret og symbolsk, bryder programmet decideret med kulturelle tabuer. Tabuer som mødre, der forlader deres børn, voldtægt og vold imod kvinder, ikke bare foretaget af mænd i lokalsamfundet, men også af politiet, prostitution, børn der lever på gaden, og unge kvinder, der får børn uden af kende faderen. Samtidig afslører programmet et samfund, som hverken er i stand til fuldt ud at forholde sig til disse spørgsmål eller støtte pigerne til at få et bedre liv.

Man kan argumentere for, at programmet på den ene side afdækker hykleriet i et samfund, der forestiller sig selv som et samfund, der er særligt omsorgsfuldt, beskytter af familieværdier og respekterer kvinden, alt sammen med reference til islam. På den anden side bekræftes disse religiøst legitimerede værdier som det, der burde have beskyttet kvinden mod det destruktive frie seksuelle liv og de ekstreme livsbetingelser. Det er dermed ikke religionen, der er noget galt med, men snarere at 


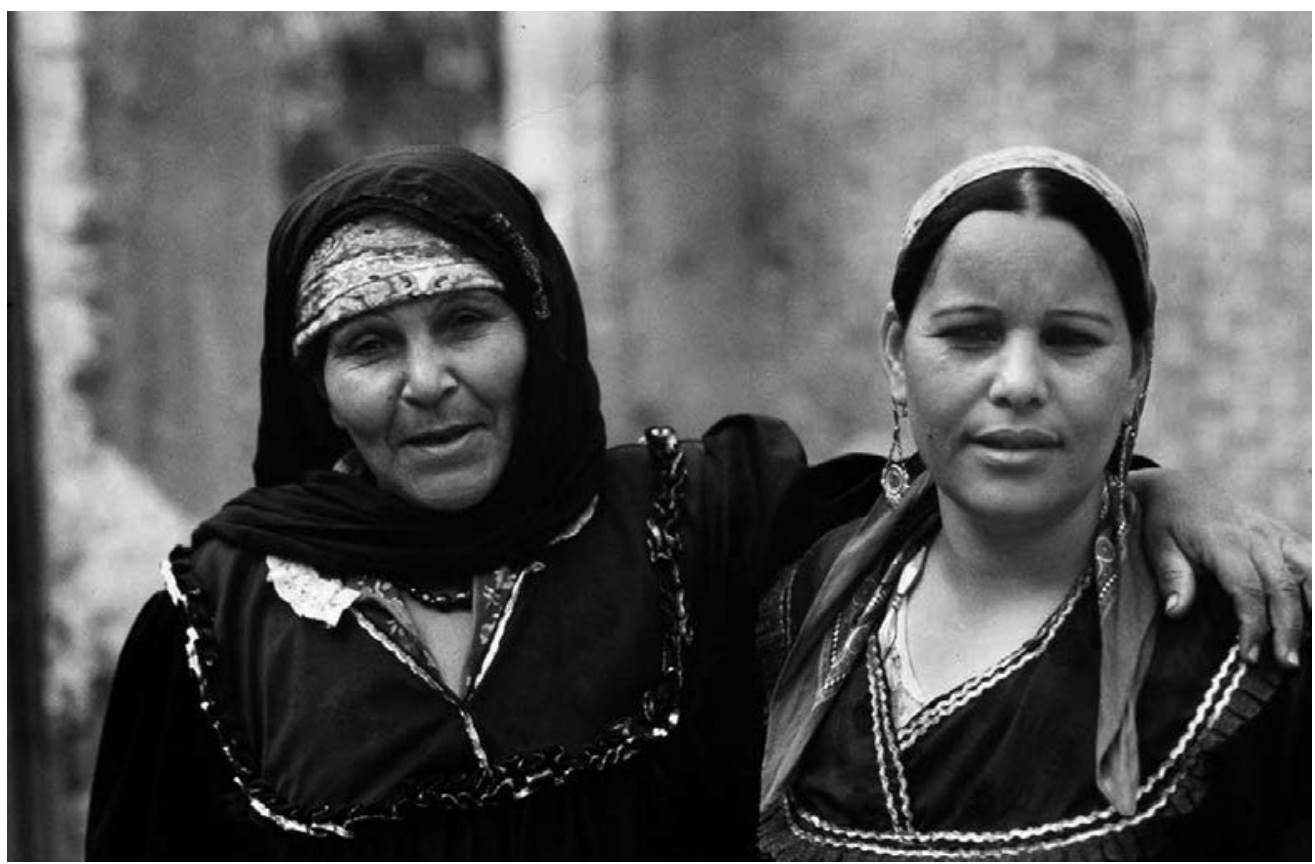

“Den muslimske kvinde” er en kategori som kanalen Iqraa i flere af programmerne operer med.

menneskene ikke følger religionen. Kvindernes seksuelle aktiviteter er et tilbagevendende tema i diskussionen med eksperterne. Nogle gange for at korrigere, hvad der i programmet fremstilles som udbredte fordomme, nemlig at den voldtagne selv har villet det, og nogle gange for at fastslå disse kvinders helt oplagte ulykke.

Eksperterne i programmet er fire mænd og to kvinder. Udover den muslimske sheikh er der en psykiater, to socialarbejdere og to forskere. De bliver igennem programmet spurgt om, hvordan man på den ene side skal forstå kvindernes adfærd og på den anden side, hvordan staten betragter og behandler pigerne.

Et af hovedtemaerne i diskussionen er spørgsmålet om kvindernes skyld. Er deres problemer selvforskyldte? Ingen af eksperterne fortolker eksemplerne som et spørgsmål om skyld. Sheikhen, som af tvværten særligt opfordres til at (for)dømme
Ayas adfærd moralsk, afviser at gøre dette. Hans måde at sno sig ud af spørgsmålet er interessant. På den ene side citerer han islamisk teologi for at påpege, at man må dømme i hver enkelt sag for sig, hvor alle omstændigheder skal tages i betragtning. Hvis en pige er under pres, kan hun ifølge ham ikke være ansvarlig. På den anden side ignorerer sheikhen samtidig de mest kontroversielle aspekter af pigens liv. Han anerkender for eksempel aldrig eksplicit den del af Ayas historie, der handler om seksuelle og voldelige overgreb eller prostitutionen. I stedet for refererer han til Ayas ægteskab, som det der gør hendes seksuelle adfærd legal ifølge islam, samtidig med at han fuldstændig ignorerer, at ægtemanden helt tydelig er ondskabsfuld og voldelig. Aya giftede sig kun med ham som en udvej for at komme væk fra gaden og samtidig antydes det, at manden fungerer som hendes alfons. Til gengæld taler 
sheikhen generelt om, hvordan enhver mand bør opføre sig i ægteskabet.

Generelt taler tre af de mandlige eksperter i meget teoretiske og principielle termer om Ayas situation, ligesom de heller aldrig anvender ordene voldtægt eller seksuelt samleje. Tabuet er på denne måde stadig tilstedeværende i programmet. De to kvindelige eksperter, hvoraf den ene bærer tørklæde, er dem, der introducerer ordet voldtægt. Og den fjerde (yngre) mand er den, der præsenterer studier om politiets og socialarbejderes seksuelle og voldelige overgreb mod piger såvel som drenge, der lever på gaden. I forhold til eksperterne repræsenterer tv-værten pigernes historier og argumenter, som de selv fremstilles af pigerne. Hun refererer flere gange under diskussionen pigernes udsagn og kommer dermed til at fremstå som et loyalt talerør for pigerne.

Der er ingen tvivl om, at programmet giver stemme til en yderst marginaliseret og stigmatiseret gruppe af kvinder i Egypten/et islamisk land, der ellers ikke har fået stemme i medierne. Samtidig afholder programmet sig fra at dømme kvinderne på et moralsk-religiøst grundlag og i stedet fremhæves samfundets ansvar. Det lykkes altså programmet, som det religiøst definerede og symbolsk iscenesatte program under titlen "Før dommedag", at stille samfundet til ansvar. Hovedargumentet er, at samfundet har ansvar for at hjælpe pigerne, og at politiet og det sociale system har behov for redskaber og mere viden for at kunne hjælpe dem. Samtidig ser det ud til, at tilstedeværelsen af kvindelige eksperter og den kvindelige studievært reelt gør en forskel på måden, temaet præsenteres og diskuteres. Den religiøse ramme for programmet og herun- der den samtidige fastslåen af de gode og sande islamiske værdier kan fortolkes som et nødvendigt redskab til at legitimere programmets brud på tabuer.

\section{Rigtig og forkert islamisk adfærd}

Fatwa-programmer er både kendt fra alJazeera og andre kanaler, hvor en muslimsk lærd besvarer spørgsmål om, hvordan man bør leve et sandt muslimsk liv i overensstemmelse med Koranen og Sunna $i$ en bestemt sammenhæng. Flere af programmerne forsøger at svare på spørgsmål relateret til at leve i en moderne og global verden og kan ses som svar på de dilemmaer, en praktiserende muslim i den forbindelse kan befinde sig i. Programgenren henvender sig generelt både til mænd og kvinder, som kan ringe til programmet med spørgsmål, eller sende fax eller e-mail.

På Iqraa er der adskillige programmer, der kan kategoriseres som fatwa-programmer. Nogle af disse er målrettet kvinder, idet de rejser spørgsmål om "den muslimske kvinde" og hendes liv set fra et islamisk perspektiv. "Den muslimske kvinde" er en kategori, som Iqraa i flere af programmerne opererer med, underforstået at "den muslimske kvinde" både har særlige idealer og forudsætninger for at efterleve disse. Det betyder ikke, at kategorien "den muslimske kvinde" altid indholdsudfyldes på samme måde, tværtimod afslører programmerne en lang række af fortolkninger eller forhandlinger af, hvad "den muslimske kvinde" er for en størrelse.

I fatwa-programmerne på Iqraa optræder både kvindelige og mandlige religiøse eksperter, der giver svar på seernes spørgsmål. Et eksempel er programmet "Kvindernes fatwa" (Fatwa anNisaa), der er et ugentligt program, der 
hver uge tager et nyt tema op til diskussion. I september 2006 var temaet kvinders økonomiske rettigheder under og efter et ægteskab. ${ }^{14}$ Programmet fastslår, at kvinder har ret til at arbejde. De penge, hun tjener, har hun ret til at gemme til og bruge på sig selv, fordi hendes ægtefælle/far/bror ifølge islam har forsørgerpligt over for hende. Hvis hun gerne vil, kan hun bruge sine penge på at støtte familien økonomisk. Programmet slutter med at konkludere, at den muslimske kvinde økonomisk har flere rettigheder end manden.

Et andet afsnit af samme program blev sendt i april 2005 og havde temaet "kvindelige imamer". Emnet var fremprovokeret af en arabisk-amerikansk kvinde, Amina Wadud, der fungerer som imam ${ }^{15}$ og som fastholder, at kvindelige imamer kan fungere som imam for både kvinder og mænd. I programmet er der blandt eksperterne religiøst uddannede kvinder og mænd. ${ }^{16}$ De er i programmet enige om, at kvinder ifølge islam sagtens kan blive imamer, men at kvindelige imamer kun kan fungere som sådan for andre kvinder.

Et sidste eksempel er fra programmet "Islamisk retsvidenskab for kvinder" (Fiqh in-Nisaa) sendt juli 2005. ${ }^{\text {I7 }}$ Programmet illustrerer endnu et populært tema i islamiske programmer i form af fokusset på og argumentet for overensstemmelse mellem et islamisk og et videnskabeligt syn på livet og hvordan disse to synsvinkler komplementerer hinanden. I det konkrete eksempel er temaet blødning efter fødslen, kvinders menstruationsblødninger generelt, og livmorens tilstand efter fødslen. Inden for logikken af argumentet er disse biologiske mysterier for længst blevet beskrevet og forklaret af islam i fuld overensstemmelse med, hvordan den mod- erne videnskab i dag beskriver disse fænomener. Argumentet om islams beskrivelse af disse temaer beviser ikke blot islams storhed. Det legitimerer samtidig, at man offentligt sidder og taler om emner forbundet med kønnenes biologi og kvinders seksualitet, som ellers har været stærkt tabuiserede, i det mindste i det offentlige rum. Endnu engang kommer islam til at fungere som legitimering af en mere moderne tilgang til traditionelt tabuiserede kønsrelaterede spørgsmål. Noget man i øvrigt kan genfinde på Iqraa’s hjemmeside og på mange andre islamiske hjemmesider, hvor seere eller læsere stiller spørgsmål om for eksempel onani og forskellige former for seksuelt samkvem, som oral- og analsex.

De tre eksempler på klassiske diskussioner om ret islamisk adfærd kan ses som eksempler på, at de religiøse kvindeprogrammer rejser spørgsmålene om kvinders rettigheder, lighed mellem kønnene og promoverer en åbenhed, hvor kvindens biologiske funktioner og seksualitet kan diskuteres åbent. Samtidig er formålet information og undervisning. Den islamiske ramme for programmerne giver dem legitimitet og sikrer samtidig traditionen. Denne åbenhed understreges af, at man i stigende grad hører muslimer henvise til citatet "der er ingen generthed i religionen" (la haya fi ad-Din). Et citat fra den islamiske tradition kan dermed legitimere, at alt kan diskuteres i islams navn.

\section{Den rette partner}

En tredje slags programmer på islamisk satellit-tv er, hvad man kan kalde livsstilsprogrammer. Det dækker over et bredt koncept af programmer, der beskæftiger sig med alt fra madlavning, mode og sundhed 
til familieliv, ægteskab og børneopdragelse. ${ }^{18}$ Et eksempel er programmet "Unge, der ønsker at gifte sig” (Shabaab aiyz yatgawiz), der er et ugentligt program. ${ }^{19}$

Eksperterne i studiet har enten en religiøs eller sekulær uddannelsesmæssig baggrund, og indimellem eksperternes diskussioner interviewes folk på gaden om deres mening eller erfaring i forhold til et specifikt emne. Temaer for programmet kan fx være: Hvordan finde den rette partner? Hvad er ægteskab ifølge traditionen, ifølge islam, og hvad er det ifølge en moderne livsstil? Hvor længe bør forlovelsesperioden være? Hvad er singlens problemer? Hvilke problemer kan der være i et ægteskab?

Ideen er, at alle disse spørgsmål diskuteres og besvares fra en islamisk synsvinkel. Det er karakteristisk for programmet, at diskussionen præsenteres som meget afslappet med masser af vittigheder og latter mellem eksperterne, som om de sad og snakkede hjemme over kaffen. Denne atmosfære understreges af iscenesættelsen, hvor gæsterne i studiet sidder i to sofaer, med værtinden i midten, i hvad der fremstår som en moderne dagligstue. Antallet af kvindelige gæster overstiger for det meste antallet af mænd, og man kan til dels se showet som en flytning af hverdagens kvindesnak fra hjemmet til et hjemliggjort tv-studie.

Programmet ligger i forlængelse af de andre kvindeprogrammer, idet det rejser spørgsmål til moderne livsstil samtidig med, at det forsvarer centrale traditionelle værdier. Der sættes for eksempel aldrig spørgsmålstegn ved, at sex før ægteskabet er forkert, og at det, der holder familien sammen, er moralske værdier og religion.
Den rette partner er derfor først og fremmest en troende og religiøs praktiserende muslim, som kender sin religion og tjener Gud. Det er det mest vigtige. På den anden side, udfordrer programmet jævnligt traditionelle praksisser som, at det er forældrene, der vælger ægtefællen, eller at størrelsen af medgiften (al-mahr) er

De to kvindelige eksperter, hvoraf den ene boerer tørkloede, er dem, der introducerer ordet voldtoegt.

vigtigere end følelserne mellem de kommende ægtefæller. Programmet slår fast, at det er vigtigt at lytte til ens forældre, men at forældrene også bør lytte til og forstå de unge mennesker, og hvad der er vigtigt for dem i dagens samfund. Medgiften bør være rimelig, og man skal ikke forlange store lejligheder og dyre møbler.

Programmet afspejler ideen om, at det er nødvendigt at gøre op med traditionelle praksisser og i stedet lade de religiøse værdier styre, samtidig med at kvinderne bør gives en mere uafhængig rolle i samfundet og familien, uden at det er på bekostning af moralske værdier. Islam bliver på denne måde på den ene side et redskab til at modernisere familiemønstre og kønsroller. På den anden side kan opgøret med traditionelle praksisser som for eksempel en mindre medgift og en mindre lejlighed ses som en hurtigere vej til giftermål og dermed en måde at mindske risikoen for før-ægteskabelig sex. Dermed er "opgøret" med traditionen samtidig en fastholdelse af traditionel religiøs moral.

En begrænsning ved flere af de pro- 
grammer, man kan kategorisere som livsstilsprogrammer, er, at de primært rejser problemstillinger af relevans for middelklassen eller overklassen. Det gør de ved at give eksempler fra praksisser og livsstile, der er uopnåelige for fattige kvinder og som generelt ligger langt fra de laveres klassers muligheder $i$ et hvilket som helst arabisk land.

\section{Konklusion}

Fremstillingen af de muslimske kvinder på Iqraa er, som det gerne skulle have fremgået, mangfoldig. "Den muslimske kvinde" er ikke en tavs, tilsløret kvinde, symboliserende islamisternes kvindeundertrykkelse, som hun ofte er blevet fremstillet som. ${ }^{20}$ Fremstillingerne af "den muslimske kvinde” i programmerne på Iqraa er langt mere komplekse og giver stemme til kvinder, der identificerer en mangfoldighed af identiteter fra omvendte skuespillerinder, religiøse lærde, sekulære socialarbejdere, kommende hustruer, til voldsramte udsatte kvinder, der lever på gaden. Islam ser i kanalens forskellige fortolkninger ud til at kunne rumme betydeligt flere kvindeidentiteter end hustruen, moren og søsteren.

Selv om kanalen Iqraas formålserklæring ikke umiddelbart kan skelnes fra ERTUs krav om beskyttelse af de religiøse og traditionelle værdier, formår Iqraa alligevel at give en fremstilling af muslimske kvinder som havende en aktiv rolle i det offentlige rum. Forskellen til ERTU er, at hvor ERTU $i$ angst for at støde religionen ofte undgår at inddrage denne, tager Iqraa udgangspunkt i religionen. Hermed sætter de ikke normen om religionens placering i samfundet på spil, men kræver forandring netop med henvisning til denne. Fordi de stiller sig med religionen i ryggen kan de behandle og diskutere kontroversielle og tabuiserede emner uden at blive beskyldt for at forlade religionen.

Det betyder samtidig, at hvor programmerne bliver udtryk for en tilpasning til moderne livsstil, er det uden at opgive den moralske orden. Seksualiteten forventes stadig at være under kontrol og familien den bærende enhed i samfundet. Der er altså grænser for liberaliseringen af kønsidentiteterne og muligheden for at sætte spørgsmål ved familiens strukturer og værdier. ${ }^{21}$ På samme måde er der grænser for kritikken af islam. Fortolkningerne af islam udfordres, kritiseres og diskuteres, men islam som fundament står ikke til diskussion. At islam er grundlaget er en fremherskende synsvinkel igennem alle programmer på Iqraa, men det lukker altså ikke for muligheden for forskellige fortolkninger, men åbner tværtimod for et krav til de islamiske lærde om at kunne tage stilling til den virkelighed, hvori kvinder (og mænd) lever. På denne baggrund viser eksemplerne på programmer på Iqraa, at islam på den ene side kan fungere som basis for forandring af kvinders rettigheder og på den anden side kan bruges til at legitimere nye kønsidentiteter i Mellemøsten.

$$
\cdot f \cdot
$$

I Se fx Alterman, Jon B.: New Media, New Politics? From Satellite Television to the Internet in the Arab World. The Washington Institute for Near East Policy, Washington I998; Galal, Ehab: "Al-Jazeera - borgerlig offentlighed i den arabiske medieverden" i: Lars Qvortrup (red.): Mediernes II. September. Gads Forlag, København 2002.

2 Se fx Amin, Hussein: "Arab Women and Satellite Broadcasting" i TBS, No. 6, Spring/Summer 200I. http://www.tbsjournal.com/Archives/Springor/Amin2 .html; Sakr, Naomi (ed.): Women and Media in the Middle East. Power through self-expression. I.B. Tauris, London, 2004. 
3 Om islamisk feminisme, se fx: Fernea, Elizabeth Warnock: In Search of Islamic Feminism: One Woman's Global Journey, Anchor, Jacksonville I998; Yamani, Mai: Feminism and Islam: Legal and Literary Perspectives. New York University Press, New York 1996; Mojab, Shahrzad: 'Theorizing the Politics of 'Islamic Feminism' i Feminist Review, No 69, Winter 200I, s. I24-146.

4 Iqraa betyder læs. Det er det første ord, der blev åbenbaret af Gud via englen Gabriel til profeten Mohammed.

5 Sakr, Naomi: "Women-Media Interaction in the Middle East: An Introductory Overview", i Naomi Sakr (ed.): Women and Media in the Middle East. Power through self-expression. I.B. Tauris, London 2004, s. 9.

6 Ramzi, Nahed: al maraa wa al Ilaam fi aalam mutaghayr (The Woman and the Media in a Changing World). Maktabit al-Usra, Kairo 2004.

7 Khatib analyserer egyptiske films forskellige fremstillinger af hvordan kvinder deltager $\mathrm{i}$ den nationale udvikling som symboler og som aktører i Khatib, Lina: "The Orient and its Others: Women as tools of Nationalism in Egyptian Political Cinema", i Naomi Sakr (ed.): Women and Media in the Middle East. Power through self-expression. I.B. Tauris, London 2004.

8 Ramzi 2004: 94.

9 Sakr (2004) nævner for eksempel programmet Lil Nisaa Faqat (Kun for kvinder) på al-Jazeera.

Io Sunna refererer til praksisser foretaget og godkendt af profeten Mohammed og som danner præcedens for ret islamisk adfærd.

II Se http://www.iqraatv.com

I2 Fatwa er et religiøst råd givet af en islamisk lærd

I3 Det første program blev sendt den I8. september, det andet program den 25 . september 2006 .

I4 Fatawi an-Nisaa - Fatawi ramadaaniya 2006-09-23.

I5 Amina Wadud ledte en fredagsbøn i New York i marts 2005 .

I6 2005-04-24 fatwa in-Nisa at Iqraa.

I7 2005-07-I3 Fiqh in-Nisaa at Iqraa.

I8 Et eksempel er 'Et øjeblik for din sundhed' (Lahza li sihitik) sendt 2I-IO-2006 på Iqraa.

I9 2005-09-I7 på Iqraa.

20 Khatib 2004: 73.

2I Amin (200I). 